\title{
Ethnobotanical investigations among tribes in Madurai District of Tamil Nadu (India) S Ignacimuthu*1, M Ayyanar ${ }^{1}$ and Sankara Sivaraman $\mathrm{K}^{2}$
}

Address: ${ }^{1}$ Entomology Research Institute, Loyola College, Chennai, India and ${ }^{2}$ Centre for Research \& Post Graduate Studies in Botany, AyyaNadar JanakiAmmal College, Sivakasi, India

Email: S Ignacimuthu* - eri_lc@hotmail.com; M Ayyanar - ayyaneri@gmail.com; Sankara Sivaraman K - sankarasivaramank@yahoo.co.in

* Corresponding author

Published: II May 2006

Journal of Ethnobiology and Ethnomedicine 2006, 2:25 doi:10.1 186/1746-4269-2-25

This article is available from: http://www.ethnobiomed.com/content/2/1/25

(c) 2006 Ignacimuthu et al; licensee BioMed Central Ltd.

This is an Open Access article distributed under the terms of the Creative Commons Attribution License (http://creativecommons.org/licenses/by/2.0), which permits unrestricted use, distribution, and reproduction in any medium, provided the original work is properly cited.
Received: 30 December 2005

Accepted: II May 2006

\begin{abstract}
Background: An ethnobotanical survey was carried out to collect information on the use of medicinal plants in Southern Western Ghats of India (Madurai district, Tamil Nadu). Information presented in this paper was gathered from the paliyar tribes using an integrated approach of botanical collections, group discussions and interviews with questionnaires in the years $1998-$ 1999. The informants interviewed were 12 among whom 4 were tribal practitioners.

Results: A total of 60 ethnomedicinal plant species distributed in 32 families are documented in this study. The medicinal plants used by paliyars are listed with Latin name, family, local name, parts used, mode of preparation and medicinal uses. Generally, fresh part of the plant was used for the preparation of medicine.

Conclusion: We observed that the documented ethnomedicinal plants were mostly used to cure skin diseases, poison bites, stomachache and nervous disorders. The results of this study showed that these tribal people still depend on medicinal plants in Madurai district forest areas.
\end{abstract}

\section{Background}

Globally, about $85 \%$ of the traditional medicines used for primary healthcare are derived from plants [1]. Traditional medicine and ethnobotanical information play an important role in scientific research, particularly when the literature and field work data have been properly evaluated [2]. India is one of the twelve mega-biodiversity countries of the World having rich vegetation with a wide variety of plants with medicinal value. In many countries, scientific investigations of medicinal plants have been initiated because of their contribution to healthcare. Herbal medicines have good values in treating many diseases including infectious diseases, hypertension, etc. That they can save lives of many, particularly in the developing countries, is undisputable [3].
India possesses a total of 427 tribal communities [4] and over 275 papers have been published on specific ethnic groups [5]. Interest in traditional medicine in India has continuously been increasing; recently, various ethnobotanical studies have been reported to explore the knowledge from the various tribals of Tamil Nadu [6-13].

Even today many local and indigenous communities in the Asian countries meet their basic needs from the products they manufacture and sell based on their traditional knowledge. Herbal drugs obtained from plants are believed to be much safer; this has been proved in the treatment of various ailments [14]. Rural communities, in particular paliyar tribes, depend on plant resources mainly for herbal medicines, food, forage, construction of 
dwellings, making household implements, sleeping mats, and for fire and shade. Rural people not only depend on wild plants as sources of food, medicine, fodder and fuel, but have also developed methods of resource management, which may be fundamental to the conservation of some of the world's important habitats [15].

The objective of this study was to assess the richness of ethnomedicinal plant species used by the paliyar tribes in Madurai district forest areas and the traditional medical practices of the people. Similar ethnobotanical studies have been reported in several parts of India to protect the traditional knowledge from disappearing [5,12,16-19]. Documenting the indigenous knowledge through ethnobotanical studies is important for the conservation of biological resources as well as their sustainable utilization.

\section{Setting and the people Paliyar tribals}

The indigenous people of the study area are called Paliyar/ Paliyan. They are found in the hilly regions of Madurai, Dindigul, Theni, Tirunelveli and Virudhunagar districts. It is believed that Paliyars are indigenous people of Palani hills (Situated near to Kodaikanal - a famous tourist place). In the Palani hills they are found at an altitude of upto $2200 \mathrm{~m}$. Generally paliyars are illiterate and they speak Tamil (Mother tongue of Tamil Nadu). Paliyars, when compared to various tribal communities in Tamil Nadu constitute relatively a small group [20].

Physically they are similar to the Semong of Malaya and other Indian tribal communities [21,22]. Historically, these tribal communities have survived on their traditional knowledge base. Traditional medicines are the primary healthcare resources for the paliyar tribes to protect their health. Tribal practitioners are the curators of the tribal society and they have a good knowledge of medicinal plants, diseases and treatment using plants.

\section{Type of paliyars}

Paliyars can be grouped into three categories based on their life styles, namely, nomadic, semi nomadic and settled. Nomadic paliyars don't build houses; they live temporarily in rock caves called 'pudai'. Semi nomadic paliyars build temporary houses and confine themselves to small territories. Most of their huts are dark with no window or any other opening to admit air. Settled Palizars are more or less urbanized and live as agricultural laborers. Importance of traditional and folk medicine in the treatment of various human ailments is well recognized amongst these people.

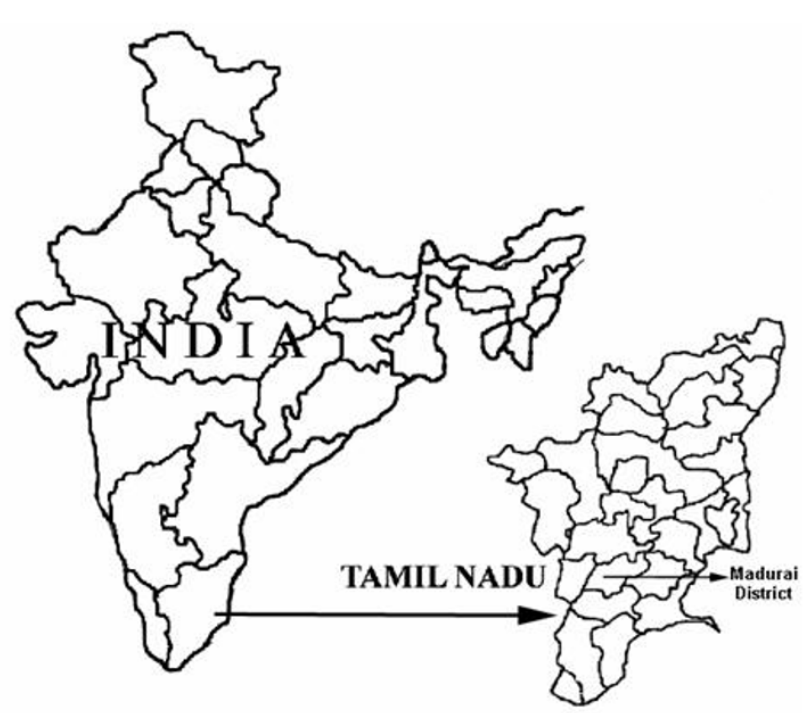

Figure I

Location of the area studied in Tamil Nadu, India.

\section{Methods}

\section{Description of the study area}

The Western Ghats, a chain of mountains in the western peninsular India extending from Tapti river valley in Gujarat to Kanyakumari in Tamil Nadu, is about $1600 \mathrm{~km}$ long in North-South direction. The study area concentrates in and around the Madurai district forest areas (Figure. 1) located in Tamil Nadu, South India. The area of investigation approximately lies between $85^{\circ} 0^{\prime}$ to $89^{\circ} 0^{\prime}$ longitude and $28^{\circ} 0^{\prime} 37^{\circ}$ to $0^{\circ}$ latitude. Every village has several paliyar hamlets. Their hamlets are found in different elevations from $300 \mathrm{~m}$ to 2,200 MSL. There are a number of hill ranges in the study area. Temperature ranges from $12^{\circ}$ to $25^{\circ}$ during March - April in high hill ranges and averages between $20^{\circ}$ during December and $38^{\circ}$ during April - May.

\section{Ethnobotanical survey}

The fieldwork was conducted in several villages around Madurai district forest areas during April 1998 to November 1999 as part of a study of Ethnobotanical Wealth of Paliyar Tribals in Tamil Nadu [20]. More than 500 families and nearly 3000 members of paliyars are found in the study area. During the stay, their daily activities were closely observed and interpersonal contacts were established by participating in several of their social and religious ceremonies such as marriages, rituals and curing sessions. There were 12 informants $(9$ males and 3 females) between the ages of 32 to 78 in the study area. Among them 5 were farmers, 3 were housewives and 4 regular tribal practitioners. 


\section{Interviews with tribal practitioners}

Ethnobotanical data were collected according to the methodology suggested by Jain [23]. The ethnobotanical data (local name, mode of preparation, medicinal uses) were collected through questionnaire, interviews and discussions among the tribal practitioners in their local language. Our questionnaire allowed descriptive responses on the plant prescribed, such as part of the plant used, medicinal uses, detailed information about mode of preparation (i.e., decoction, paste, powder and juice), form of usage either fresh or dried and mixtures of other plants used as ingredients. The Flora of Presidency of Madras [24] and The Flora of Tamil Nadu Carnatic [25] were used to ascertain the nomenclature. The voucher specimens in duplicate were deposited in the herbarium of Entomology Research Institute, Loyola College, Chennai (India).

\section{Results and discussion}

In Table 1, data obtained from the field survey are presented. In this study 60 plant species belonging to 32 families distributed in 53 genera have been recorded. These contribute to 81 remedies. Many species of the family Acanthaceae and Asclepiadaceae are frequently used (21 remedies from 12 species); the Euphorbiaceae and Solanaceae contribute to 9 remedies from 8 species. The informations collected from this study are in agreement with the previous reports [5-12], [16-19].

As seen in Table 1, common health ailments in the study area were skin problems such as wounds, cuts, burns and skin diseases and the largest number of the remedies (16 remedies from 16 species) were used to treat these ailments. Kani tribals in Tirunelveli hills of Tamil Nadu were using 14 plants for the treatment of skin problems [13]; 52 herbal preparations from 31 plants were used for skin diseases by tribals of Uttar Karnataka district, a nearest state of Tamil Nadu [18] and people of Eastern Cape Province, South Africa used 38 plant species for the treatment of wounds [27].

On the other hand, 14 remedies were used to alleviate problems of the respiratory system such as cold, cough, asthma and fever. Among the plants surveyed, Adhatoda zeylanica and Vitex negundo (4 remedies) are used frequently for the preparation of medicines for the treatment of respiratory problems. Respiratory problems are the most encountered illness and there may be hardly any person who has not suffered from respiratory problems in his lifetime [28]. 8 remedies were used against gastrointestinal problems such as stomachache, abdominal pain and ulcer. A previous study (29) has reported the use of 21 medicinal plants from 20 families to treat gastro-intestinal complaints in the same community. 5 remedies were used against inflammatory diseases such as rheumatism, fractured bones and joint pains.
Leaves of Acacia caesia, Asystasia gangetica, Oxalis corniculata, rhizomes of Costus speciosus, Dioscorea opositifolia, fruits of Gmelina arborea, and seeds of Piper nigrum are used as edible plants by the local inhabitants of the study area. The tribal people mostly eat vegetables of leafy varieties, which grow as wild weeds.

There are two types of tribal healers found in the study area namely herbalists and ritualists. Herbalists treat patients only by using plant resources. They diagnose diseases based on the symptoms told by the patients as well as based on their personal experience in treating human ailments. Ritualists believe that specific spirit causes ailments. The whole healing ceremony takes about a day. The preparation of medicines and treatment of diseases connected with the tribal healthcare are accompanied by elaborate rituals and music as previously observed in the case of Mikirs of India [30].

Paliyar tribal practitioners use specific plant parts and specific dosages for the treatment of ailments. The plant products are consumed raw or in the form of a decoction, as infusion for oral treatment and as burnt product, ointments or raw paste when applied externally. The parts of the plant most used for medicinal purposes are leaves, root, stem, fruits, the complete aerial parts, the whole plant, barks (root and stem) and flowers (including the flowering heads) in decreasing order. Internal uses (used in 36 of the cases) are predominating over external (used in 30 cases) uses. Juice (almost mix with water and goat's or cow's milk) and paste are the main methods of preparation, either for oral or for external administration. For topical use, the most important methods used are direct application of the paste or ointment (with oil).

Often, people use more than one plant either separately or mixed together. They mix several plants as ingredients to cure diseases immediately. Generally, fresh part of the plant is used for the preparation of medicine. When fresh plant parts are not available, dried parts are also used. Majority of medicinal plants are used as simple drugs and some plants are used with some other plant parts.

Paliyar tribes use some plants to prepare agricultural implements. For example Terminalia bellirica and Haldenia cordifolia are used to prepare ploughs; they prepare musical instruments from the wood of Gmelina arborea. They crush the fruits of Solanum erianthum and apply topically on their legs, while entering into forest to protect from leech-bite. From this account it is clear that the paliyar tribals like other ancient tribals [31] possess the ability to discern the character of various plants and their beneficial properties. It is interesting to note that such a way of life, particularly with respect to healthcare practices has hardly undergone any change even in the present day. 
Table I: Ethnomedicinal plant species, plant parts used and ailments cured by the Paliyar tribes in Madurai District of Tamil Nadu, India

\begin{tabular}{|c|c|c|c|}
\hline $\begin{array}{l}\text { Therapeutic indication and } \\
\text { associated plants }\end{array}$ & Local Name & Family & Parts used and Ethnomedicinal preparation \\
\hline \multicolumn{4}{|l|}{ Asthma } \\
\hline Solanum trilobatum L. & Thoodhuvalai & Solanaceae & Juice of leaves is taken orally for seven days. \\
\hline Adhatoda zeylanica Medicus. & Adathodai & Acanthaceae & Leaf paste is taken orally. \\
\hline \multicolumn{4}{|l|}{ Cold } \\
\hline Adhatoda zeylanica Medicus. & Adathodai & Acanthaceae & Leaf powder is mixed with water and taken orally in the morning. \\
\hline Boswellia serrata Roxb. Ex Colebr. & Kungiliyam & Burseraceae & $\begin{array}{l}\text { Powdered resin is sprayed on burning charcoal \& the smoke is } \\
\text { inhaled. }\end{array}$ \\
\hline Plectranthus coleoides Benth. & Omavalli chedi & Lamiaceae & Juice of leaves is taken internally. \\
\hline Solanum trilobatum L. & Thoodhuvalai & Solanaceae & $\begin{array}{l}\text { Juice of leaves is taken orally for seven days early morning until } \\
\text { cure. }\end{array}$ \\
\hline Terminalia chebula Retz. & Kadukkai maram & Combretaceae & $\begin{array}{l}\text { Powdered fruit is mixed with water or cow's or goat's milk and } \\
\text { taken internally. }\end{array}$ \\
\hline Vitex negundo L. & Notchi & Verbenaceae & $\begin{array}{l}\text { Fresh leaves are boiled with water and the vapour is inhaled twice a } \\
\text { day. }\end{array}$ \\
\hline \multicolumn{4}{|r|}{ ק } \\
\hline Adhatoda zeylanica Medicus. & Adathodai & Acanthaceae & Leaf powder is mixed with water and taken orally in the morning. \\
\hline Terminalia chebula Retz. & Kadukkai maram & Combretaceae & $\begin{array}{l}\text { Powdered fruit is mixed with the water or cow's or goat's milk and } \\
\text { taken internally. }\end{array}$ \\
\hline Vitex negundo L. & Notchi & Verbenaceae & $\begin{array}{l}\text { Fresh leaves are boiled with water and the vapour is inhaled twice a } \\
\text { day. }\end{array}$ \\
\hline \multicolumn{4}{|r|}{ r } \\
\hline $\begin{array}{l}\text { Andrographis lineata Wallich ex } \\
\text { Nees. }\end{array}$ & Siriyanangai & Acanthaceae & Leaf powder is mixed with cow's or goat's milk and taken orally. \\
\hline Costus speciosus (J. Koen.) Smith. & Koshtam & Zingiberaceae & Powdered leaves are taken internally with cow's milk. \\
\hline $\begin{array}{l}\text { Gymnema sylvestre (Retz.) R. Br. ex } \\
\text { Roem. \& Schult. }\end{array}$ & Sirukurinjan & Asclepiadaceae & $\begin{array}{l}\text { Powdered leaves are mixed with cow's milk and boiled rice, kept } \\
\text { over night and taken internally twice a day. }\end{array}$ \\
\hline \multicolumn{4}{|l|}{ Diarrhoea } \\
\hline Cipadessa baccifera (Roth.) Miq. & Pulippan chedi & Meliaceae & $\begin{array}{l}\text { Paste of leaves is mixed with the cup of water or milk and taken } \\
\text { orally. }\end{array}$ \\
\hline \multicolumn{4}{|l|}{ Dysentery } \\
\hline Acalypha fruticosa Forsskal. & Chinni chedi & Euphorbiaceae & Decoction of leaves taken orally. \\
\hline \multicolumn{4}{|l|}{ Eye infections } \\
\hline Alangium salvifolium (L.f.) Wangerin. & Alinji & Alangiaceae & One or two drops of fruit juice is poured in the eyes. \\
\hline \multicolumn{4}{|l|}{ Fever } \\
\hline Adhatoda zeylanica Medicus. & Adathodai & Acanthaceae & Leaf decoction is taken internally twice a day until cure. \\
\hline Hemidesmus indicus H.f. & Nannari & Asclepiadaceae & Decoction of whole plant is taken internally. \\
\hline Terminalia chebula Retz. & Kadukkai maram & Combretaceae & $\begin{array}{l}\text { Powdered fruit is mixed with the water or cow's or goat's milk and } \\
\text { taken internally. }\end{array}$ \\
\hline Vitex negundo L. & Notchi & Verbenaceae & $\begin{array}{l}\text { Fresh leaves are boiled with water and the vapour is inhaled twice a } \\
\text { day. }\end{array}$ \\
\hline \multicolumn{4}{|r|}{ - } \\
\hline Ceropegia candelabrum L. & Perun kodi & Asclepiadaceae & Paste of leaves is applied on forehead. \\
\hline Pergularia daemia (Fors.) Chiov. & Veli parutthi & Asclepiadaceae & Fresh leaves are boiled with water and the vapour is inhaled. \\
\hline Vitex negundo L. & Notchi & Verbenaceae & $\begin{array}{l}\text { Fresh leaves are boiled with water and the vapour is inhaled twice a } \\
\text { day. }\end{array}$ \\
\hline \multicolumn{4}{|r|}{ / } \\
\hline Asparagus racemosus Willd. & $\begin{array}{l}\text { Thanneer vittan } \\
\text { kilangu }\end{array}$ & Liliaceae & $\begin{array}{l}\text { Paste of tender and mature leaves is applied topically on the heels } \\
\text { before going to bed. }\end{array}$ \\
\hline $\begin{array}{l}\text { Drymaria cordata (L.) Roem. \& } \\
\text { Schult. }\end{array}$ & Kodi charai & Caryophyllaceae & $\begin{array}{l}\text { Paste of leaves is applied over the heels before going to bed } \\
\text { regularly till cure. }\end{array}$ \\
\hline Rubia cordifolia L. & Kalutharupan chedi & Rubiaceae & Root paste is applied topically on heel before going to bed. \\
\hline \multicolumn{4}{|l|}{ Jaundice } \\
\hline Centella asiatica (L.) Urban. & Vallarai & Umbelliferae & $\begin{array}{l}\text { Juice of leaf is mixed with equal amount of goat's milk and taken } \\
\text { orally for seven days. }\end{array}$ \\
\hline \multicolumn{4}{|l|}{ Menorrhagia } \\
\hline Hemidesmus indicus H.f. & Nannari & Asclepiadaceae & $\begin{array}{l}\text { Paste of root is mixed with water or cow's milk and taken } \\
\text { internally twice a day. }\end{array}$ \\
\hline \multicolumn{4}{|l|}{ Nervous disorders } \\
\hline Bischofia javanica Blume. & Romaviruksha pattai & Bischofiaceae & Paste of stem bark is applied externally on the affected parts. \\
\hline
\end{tabular}


Table I: Ethnomedicinal plant species, plant parts used and ailments cured by the Paliyar tribes in Madurai District of Tamil Nadu, India (Continued)

\begin{tabular}{|c|c|c|c|}
\hline Blepharis maderaspatensis (L.) Roth. & Vettukaaya pachilai & Acanthaceae & $\begin{array}{l}\text { Leaf paste is mixed with the powdered black gram, crushed onion } \\
\text { and white yolk of one egg and the mixture is applied topically over } \\
\text { the fractured bones. }\end{array}$ \\
\hline Euphorbia antiquorum L. & Sathura kalli & Euphorbiaceae & Stem latex is applied topically on skin to get relief from body pain. \\
\hline $\begin{array}{l}\text { Gymnema sylvestre (Retz.) R. Br. ex } \\
\text { Roem. \& Schult. }\end{array}$ & Sirukurinjan & Asclepiadaceae & Paste of leaves is applied externally. \\
\hline Phlebophyllus kunthianum Nees. & Kurinji chedi & Acanthaceae & $\begin{array}{l}\text { Fresh leaves and bark are heated with gingelly oil and applied } \\
\text { externally on affected part of the body. }\end{array}$ \\
\hline \multicolumn{4}{|l|}{ Piles } \\
\hline Gmelina arborea Roxb. & $\begin{array}{l}\text { Perungilai/ } \\
\text { Kumilamaram }\end{array}$ & Verbenaceae & Juice of root bark is taken internally. \\
\hline \multicolumn{4}{|l|}{ Pimples } \\
\hline $\begin{array}{l}\text { Acalypha paniculata Miq. } \\
\text { Poison bites }\end{array}$ & \multicolumn{2}{|c|}{ Poison bites } & Leaf paste is applied over pimples regularly once a day until cure. \\
\hline $\begin{array}{l}\text { Andrographis lineata Wallich ex } \\
\text { Nees. }\end{array}$ & Siriyanangai & Acanthaceae & $\begin{array}{l}\text { Paste of leaves is applied externally on bitten site of scorpion and } \\
\text { snake. }\end{array}$ \\
\hline $\begin{array}{l}\text { Andrographis paniculata (Burm.f.) } \\
\text { Wall. ex Nees. }\end{array}$ & $\begin{array}{l}\text { Periyanangai or } \\
\text { Nilavembu }\end{array}$ & Acanthaceae & $\begin{array}{l}\text { Paste of leaves is applied externally on bitten site of scorpion sting } \\
\text { and snakebites. }\end{array}$ \\
\hline Tylophora indica (Burm. f.) Merr. & Nangilai & Asclepiadaceae & $\begin{array}{l}\text { Paste of leaf and root is mixed with equal amount of root paste of } \\
\text { Rauvolfia serpentina and applied externally on the spot of snakebite. } \\
\text { Leaf juice alone is also taken internally to cure snakebite. }\end{array}$ \\
\hline \multicolumn{4}{|l|}{ Skin diseases } \\
\hline Acalypha fruticosa Forsskal. & Chinni chedi & Euphorbiaceae & Leaf and root paste is applied topically on the affected places. \\
\hline Anisochilus carnosus (L.f.) Wallich. & Saetthupun thazhai & Lamiaceae & Paste of leaves is applied over the affected places. \\
\hline $\begin{array}{l}\text { Balanophora fungosa Fors and Fors. } \\
\text { var. indica. }\end{array}$ & Vaer chedi & Balanophoraceae & $\begin{array}{l}\text { Paste of the whole plant is applied over the infected part of the } \\
\text { skin. }\end{array}$ \\
\hline Clematis gouriana Roxb. Ex. DC. & Attumeesai chedi & Ranunculaceae & Paste of leaves is applied topically on affected part of the skin. \\
\hline Excoecaria crenulata $\mathrm{L}$. & Vellai thillai & Euphorbiaceae & Paste of the stem is applied on the affected part of the skin. \\
\hline Lobelia heyneana Roem. \& Schult. & Upperi chedi & Lobeliaceae & $\begin{array}{l}\text { Leaves and flowers are mixed with water and the paste is applied } \\
\text { on skin till cure. }\end{array}$ \\
\hline $\begin{array}{l}\text { Mahonia leschenaultii (Wight \& } \\
\text { Arn.) Tak. ex Gamble }\end{array}$ & Mullu kadambu & Berberidaceae & $\begin{array}{l}\text { Powdered stem bark is boiled with gingelly oil and applied over the } \\
\text { body before bath. }\end{array}$ \\
\hline \multicolumn{4}{|l|}{ Stomachache } \\
\hline Acalypha paniculata Miq. & Paruva thazhai & Euphorbiaceae & Juice of leaves is taken orally. \\
\hline $\begin{array}{l}\text { Dioscorea oppositifolia L. var. } \\
\text { tomentosa. }\end{array}$ & Nurulai/Valli kilangu & Dioscoreaceae & Paste of rhizome is taken internally. \\
\hline Elatteria cardamomum (L.) Maton. & Yelakkai & Zingiberaceae & Dried fruits are taken internally with food. \\
\hline Hemidesmus indicus H.f. & Nannari & Asclepiadaceae & Fresh leaves are taken internally. \\
\hline Plumbago zeylanica L. & Chitthira moolam & Plumbaginaceae & Powdered root is mixed with goat's milk and taken internally. \\
\hline Solanum nigrum L. & Mana thakkali & Solanaceae & $\begin{array}{l}\text { Fresh leaves are cooked with onion bulbs and cumin seeds and } \\
\text { taken along with food regularly. }\end{array}$ \\
\hline Terminalia chebula Retz. & Kadukkai maram & Combretaceae & $\begin{array}{l}\text { Powdered fruit is mixed with water or cow's or goat's milk and } \\
\text { taken internally. }\end{array}$ \\
\hline \multicolumn{3}{|l|}{ Throat infection } & Decoction of leaves is given internally. \\
\hline Acorus calamus L. & Vasambu & Araceae & $\begin{array}{l}\text { Dried rhizome is rubbed on stone with water and one or two } \\
\text { drops of watery paste are given orally to the children for clarity of } \\
\text { speech. Increased dosage will affect speech. }\end{array}$ \\
\hline \multicolumn{4}{|l|}{ To increase lactation } \\
\hline Alstonia scholaris (L.) R.Br. & Paalooram pattai & Apocynaceae & $\begin{array}{l}\text { Powdered stem is mixed with water and given orally to the } \\
\text { mother. }\end{array}$ \\
\hline \multicolumn{4}{|l|}{ To increase resistance power } \\
\hline Alpinia calcarata Rosc. & Arathi poo & Zingiberaceae & $\begin{array}{l}\text { Dried rhizome is mixed with water and two drops of juice are } \\
\text { given orally to children. }\end{array}$ \\
\hline \multicolumn{4}{|l|}{ To induce fertility } \\
\hline \multicolumn{4}{|l|}{ Toothache } \\
\hline Solanum erianthum D.Don & Malai sundai & Solanaceae & $\begin{array}{l}\text { The ripened or unripened fruits are boiled with water and the } \\
\text { vapour is inhaled once or twice a week through mouth. }\end{array}$ \\
\hline Solanum surattrense Burm. f. & Kandankathiri & Solanaceae & $\begin{array}{l}\text { Fresh or dried fruits are kept in fire and the smoke is inhaled with } \\
\text { mouth. }\end{array}$ \\
\hline Toddalia asiatica (L.) Lam. & Kindu mullu & Rutaceae & Powder of root and stem bark is used as tooth powder. \\
\hline
\end{tabular}

To reduce delivery time pain 
Table I: Ethnomedicinal plant species, plant parts used and ailments cured by the Paliyar tribes in Madurai District of Tamil Nadu, India (Continued)

\begin{tabular}{|c|c|c|c|}
\hline Plectranthus coleoides Benth. & $\begin{array}{l}\text { Mudupattan or } \\
\text { Omavalli chedi }\end{array}$ & Lamiaceae & Leaf juice is taken internally by pregnant women. \\
\hline $\begin{array}{l}\text { Pterolobium hexapetalum (Roth.) } \\
\text { Sant. \& Wagh. }\end{array}$ & Kari indu & Caesalpiniaceae & Decoction of leaves is taken internally by pregnant women. \\
\hline \multicolumn{4}{|l|}{ To stimulate appetite } \\
\hline $\begin{array}{l}\text { Asystasia gangetica (L.) T. } \\
\text { Anderson. }\end{array}$ & Valukai keerai & Acanthaceae & $\begin{array}{l}\text { Fresh leaves are cooked with cumin seeds and onion bulbs and } \\
\text { taken orally with food. }\end{array}$ \\
\hline \multicolumn{4}{|l|}{ To stimulate Hair growth } \\
\hline Bischofia javanica Blume. & Romaviruksha pattai & Bischofiaceae & Stem bark is mixed with coconut oil and applied over head. \\
\hline Plectranthus coleoides Benth. & Omavalli chedi & Lamiaceae & Juice of leaves is boiled with coconut oil and applied on head. \\
\hline Sida acuta Burm. f. & Pilla valatthi chedi. & Malvaceae & $\begin{array}{l}\text { Paste of leaves is mixed with coconut oil and applied on head } \\
\text { regularly for killing dandruffs and also for strengthening hair. }\end{array}$ \\
\hline \multicolumn{4}{|l|}{ To stupefy fish } \\
\hline $\begin{array}{l}\text { Catunaregum spinosa (Thun.) } \\
\text { Tiruvengadam }\end{array}$ & Karangai maram & Rubiaceae & Crushed unripe fruits are used. \\
\hline Sapindus emarginata Vahl. & Poondi kottai & Sapindaceae & $\begin{array}{l}\text { Unripe fruits are crushed and thrown on the running and stagnant } \\
\text { water. }\end{array}$ \\
\hline \multicolumn{4}{|l|}{ Menstrual disorders } \\
\hline $\begin{array}{l}\text { Andrographis paniculata (Burm. f.) } \\
\text { Wall. ex Nees. }\end{array}$ & $\begin{array}{l}\text { Periyanangai or } \\
\text { Nilavembu }\end{array}$ & Acanthaceae & $\begin{array}{l}\text { Leaf juice is taken orally during menstruation to prevent excessive } \\
\text { bleeding. }\end{array}$ \\
\hline \multicolumn{4}{|l|}{ Wounds } \\
\hline Acacia caesia (L.) Willd. & Nanjupattai & Mimosaceae & $\begin{array}{l}\text { Bark is ground with water and applied topically over the affected } \\
\text { part. }\end{array}$ \\
\hline Acacia leucophloea (Roxb.) Willd. & Sarayapattai maram & Mimosaceae & Paste of fresh bark is applied topically on cuttings until cure. \\
\hline $\begin{array}{l}\text { Anisomeles malabarica (L.) R. Br. Ex. } \\
\text { Sims. }\end{array}$ & Paei miratti & Lamiaceae & $\begin{array}{l}\text { Paste of stem is mixed with coconut oil and applied over the } \\
\text { affected places. }\end{array}$ \\
\hline Blepharis maderaspatensis (L.) Roth. & Vettukaaya pachilai & Acanthaceae & Paste of leaves is mixed with limejuice and applied on cuts. \\
\hline Clausena dentata (Willd.) Roem. & Anai thazhai & Rutaceae & Paste of leaves is applied over the affected parts. \\
\hline $\begin{array}{l}\text { Cryptolepis buchananii Roem \& } \\
\text { Schul. }\end{array}$ & Paalkodi/Karunkodi & Asclepiadaceae & Stem latex ( $5-10$ drops) is applied on the affected places. \\
\hline Plectranthus coleoides Benth. & Omavalli chedi & Lamiaceae & Paste of leaves is applied over wounds till cure. \\
\hline Solanum nigrum L. & Mana thakkali & Solanaceae & Fresh leaf paste is applied externally on cuts. \\
\hline Sonchus oleraceus L. & Kaalaadi pachilai & Asteraceae & $\begin{array}{l}\text { Leaves are ground with the equal amount of leaves of Smilax } \\
\text { zeylanica and applied externally on the cuts once a day till cure. }\end{array}$ \\
\hline
\end{tabular}




\section{Conclusion}

This study shows that knowledge and usage of herbal medicine for the treatment of various ailments among paliyar tribes is still a major part of their life and culture. They use forest plants, weeds, fruit plants, vegetables, spices, ornamental plants, ferns and many others as traditional medicine. Although many of these species are known as medicinal plants, others are mainly used for nonmedicinal purposes such as preparing agricultural implements. Adhatoda zeylanica, Vitex negundo, Plectranthus coleoides, and Piper nigrum are the leading species used as remedies against a variety of complaints.

The data collected show that majority of the remedies are taken orally. Most of the reported preparations are drawn from a single plant; mixtures are used rarely. In other parts of the country, the use of mixtures of plant species in treating a particular ailment is fairly common [6-13]. Generally, the people of the study area still have a strong belief in the efficacy and success of herbal medicine. The results of the present study provide evidence that medicinal plants continue to play an important role in the healthcare system of this tribal community.

\section{Acknowledgements}

The authors are grateful to the Mac Arthur Foundation, USA, for financial assistance. We acknowledge the help provided by all the people of paliyar tribals of Madurai district forest areas by sharing their knowledge on herbal medicine during our field visits.

\section{References}

I. Farnsworth NR: Screening plants for new medicines. In Biodiversity Edited by: Wilson EO. National Academy Press, Washington, DC:83-97.

2. Awadh A, Ali N, Al-rahwil K, Lindequist U: Some medicinal plants used in Yemeni herbal medicine to treat Malaria. African journal of Traditional, Complementary and Alternative Medicines 2004 I:72-76.

3. Patrick OE: Herbal Medicines: Challenges (Editorial). Tropical Journal of Pharmaceutical Research 2002, I (2):53-54

4. Kala CP: Ethnomedicinal botany of the Apatani in the Eastern Himalayan region of India. Journal of Ethnobiology and Ethnomedicine 2005, I (I I): [http://www.ethnobiomed.com/content/I/I/III].

5. Jain SK: Ethnobotany in Modern India. Phytomorphology Golden Jubilee Issue: Trends in Plant Sciences 2001:39-54.

6. Sandhya B, Thomas S, Isabel W, Shenbagarathai R: Ethnomedicinal plants used by the valaiyan community of Piranmalai hills (Reserved forest), Tamil Nadu, India - A pilot study. African journal of Traditional, Complementary and Alternative Medicines 2006 , 3(I): $101-1 \mid 4$.

7. Ayyanar M, Ignacimuthu S: Traditional Knowledge of Kani tribals in Kouthalai of Tirunelveli hills, Tamil Nadu, India. Journal of Ethnopharmacology 2005, I 02(2):246-255.

8. Ignacimuthu S, Sankara Sivaraman K, Kesavan L: Medico-ethnobotanical survey among Kanikar tribals of Mundanthurai Sanctuary. Fitoterapia 1998, 69:409-4|4.

9. Rajan S, Sethuraman M, Mukherjee PK: Ethnobiology of the Nilgiri Hills, India. Phytotherapy - Research 2002, I 6(2):98-II6.

10. Ganesan S, Suresh N, Kesavan L: Ethnomedicinal survey of lower Palni Hills of Tamil Nadu. Indian Journal of Traditional Knowledge 2004, 3(3):299-304.

II. Udayan PS, Sateesh G, Thushar KV, Indira B: Ethnomedicine of Chellipale community of Namakkal district, Tamil Nadu. Indian Journal of Traditional Knowledge 2005, 4(4):437-442.
12. Natarajan B, Paulsen BS, Korneliussen V: An Ethnopharmacological Study from Kulu District, Himachal Pradesh, India: Traditional Knowledge Compared with Modern Biological Science. Pharmaceutical Biology 2000, 38(2): | 29-138.

13. Ayyanar M, Ignacimuthu S: Ethnomedicinal plants used by the tribals of Tirunelveli hills to treat poisonous bites and skin diseases. Indian Journal of Traditional Knowledge 2005, 4:229-236.

14. Mitalaya KD, Bhatt DC, Patel NK, Didia SK: Herbal remedies used for hair disorders by tribals and rural folk in Gujarat. Indian Journal of Traditional Knowledge 2003, 2(4):389-392.

15. Gemedo-Dalle T, Maass BL, Isselstein J: Plant biodiversity and Ethnobotany of Borana Pastoralists in Southern Oromia, Ethiopia. Economic Botany 2005, 59(1):43-65.

16. Pushpangadan P, Atal CK: Ethno-medico-botanical investigations in Kerala I. Some primitive tribal of western ghats and their herbal medicine. Journal of ethnopharmacology 1984, I I(I):59-77.

17. Mahapatra AK, Panda PK: Ethno-pharmacological knowledge of Juang and Munda tribes of eastern India. International Journal of Sustainable Development and World Ecology 2002, 9(2): $15|-| 58$.

18. Harsha VH, Hebber SS, Shripathi V, Hedge GR: Ethnomedicobotany of Uttat Kannada District in Karnataka, India - plants in treatment of skin diseases. Journal of Ethnopharmacology 2003, 84(I):37-40.

19. Anis M, Sharma MP, lqbal M: Herbal Ethnomedicine Of The Gwalior Forest Division In Madhya Pradesh, India. Pharmaceutical Biology 2000, 38(4):24|-253.

20. Sankarasivaraman K: Ethnobotanical Wealth of Paliyar Tribe in Tamil Nadu Ph.D. Thesis, Manonmaniam Sundaranar University, Tirunelveli; 2000.

21. Dahmon: The Paliyars: Hill-Tribe of Palni hills (South India). Anthropos 1908, 3:19-31.

22. Gardner PM: The Paliyars. In Hunters and Gatherers Today Edited by: Marco G. Bicchieri, New York; 1972:404-4I7.

23. Jain SK: The role of botanist in folklore research. Folklore 1964, 5(4): $145-150$

24. Gamble JS: The Flora of the Presidency of Madras. Adlard \& son, LTD, London; 1935.

25. Matthew KM: The Flora of the Tamil Nadu Carnatic. In The Rapinat Herbarium St Joseph's College, Tiruchirapalli, India; 1983.

26. Natarajan B, Paulsen BS, Pushpangadan P: An Ethnopharmacological Study from the Coimbatore District, Tamil Nadu, India: Traditional Knowledge Compared With Modern Biological Science. Pharmaceutical Biology 1999, 37(5):378-390.

27. Grierson DS, Afolayan AJ: An ethnobotanical study of plants for the treatment of wounds in the Eastern Cape, South Africa. Journal of Ethnopharmacology 1999, 67:327-332.

28. Damle L: Do not scoff that cough. Heritage Amruth 2006, 2(I):05-10.

29. Muthukumarasamy S, Mohan VR, Kumaresan S, Chelladurai V: Herbal medicinal plants used by Paliyars to obtain relief from gastro-intestinal complaints. Journal of Economic and Taxonomic Botany 2003, 27(3):7| I-7|4.

30. Borthakur SK: Studies in ethnobotany of the Karbis (Mikirs) plant masticatories and dyestuffs. Glimpses of Indian ethnobotany 1981:182-190.

3I. Rajasingh GJ: Forest working plan for the Tirunelveli North Division. Government of Madras Publication, Madras; 1971:127-133. 